\title{
Implementing Public Private Partnerships in Africa: \\ The Case of Urban Water Service Delivery in Ghana
}

\author{
Maliha Abubakari \\ Department of Public Administration and Health Services Management \\ P. O. Box LG 78, University of Ghana, Accra, Ghana. \\ Tel: +233209336 $387 \quad$ E-mail: maliha2008@yahoo.com \\ Thomas Buabeng \\ Department of Public Administration and Health Services Management \\ P. O. Box LG 78, University of Ghana, Accra, Ghana. \\ Tel: +233264166400Ｅmail: tbuabeng@ug.edu.gh \\ Albert Ahenkan \\ Department of Public Administration and Health Services Management \\ P. O. Box LG 78, University of Ghana, Accra, Ghana. \\ Tel: +233246955818Ｅ-mail: aahenkan@ug.edu.gh
}

Received: January 25, 2013 Accepted: February 28, 2013 DOI: 10.5296/jpag.v3i1.3252

\begin{abstract}
The study sets out to given in-depth analysis of thePublic Private Partnership between the government of Ghana, represented by GWCL and Aqua Vitens Rand Ltd -AVRL from 2005-2011 and to generate an insight on how the implementation process faired from the perspective of implementers in particular, civil society organisations and the public utility workers union. The case study method within the qualitative approach was used for the study. The study also, made use of interview as the research instrument and respondents were purposively selected. The results of the study were subjected to an interpretative analysis combined with secondary data from the literature review. There were several grey areas in the management contract resulting in a number of ambiguities in various parts of the management contract. These ambiguities translated into delays in the implementation process. Also, there appeared to be conflict of interest on the part of GWCL, resulting in weak supervision. Political interference also weakened the structures established for the
\end{abstract}


implementation of the contract. Leadership of GWCL was weakened as result of frequent changes in leadership and the fact that leaders were mostly in acting capacities. Despite the richness of the data, the study encountered a number of difficulties including the unwillingness of some senior level staff to participate in the study limits the diversity of perspectives which otherwise would have broadened the scope of the study. The findings provide deeper understanding to public policy implementation in respect of the management contract between GWCL and AVRL. The paper particularly contributes to the challenges implementers encounter in implementing management contracts from both implementers and non-implementers perspectives. It may also contain lessons for implementers in the private sector.

Keywords: Management contract, Public Private Partnership, privatisation, water

\section{Introduction}

The public sector is defined as organisations charged with providing services for the public, although increasingly, their roles are being transformed from actual production to provision using a variety of public and private entities (Ayee 2007).In other words, the sector is in charge of government transactions. According to Ngowi (2008) the public sector is usually financed through various forms of public finance through taxation. This is often inadequate for most developing countries and the deficit is normally bridged by public borrowing and aid from donors. The sector in most developing countries has not lived up to expectation despite the support the sector has from the state in terms of investment and funding. The abysmal performance of the public sector in developing countries was captured by Okecho (1992) that a number of enterprises are experiencing low capacity utilisation, large operating losses (low profitability), low productivity and increasing illiquidity and indebtedness. The whole sector is glutted with non-productive and unmotivated labour force. The sustainability; efficiency and effectiveness of public sector services delivery are among recent and topical issues of debate and discussion (Ngowi 2008).

The ineffectiveness of the public sector in most developing countries, including Ghana, has led to the increasing demand for private sector participation (PSP) in the provision of public utilities and services. These calls have largely been made by public choice theorists. According to Grindle and Thomas (1991) the public choice theory holds that public interest will never be achieved as long as public officials remain in power and therefore the need to introduce privatisation. The diversion of public policy from state controlled to private sector participation in the production and delivery of public services stems from the belief that the private sector gets better results in terms of performance than the public sector (Rivera 1996; Tati 2005; Andres, Guasch, Haven and Forster2008).

There were several attempts at privatising some SOEs in Ghana as far back as the 1960s after the overthrow of the first Convention People's Party (CPP) Republican President. According to Young (1991) out of the fifty-two (52) state-owned industries in Ghana at the time, four (4) were out-rightly sold to Ghanaians and five (5) were put under joint venture arrangement with foreign firms. Boakye-Danquah (2000) also reported that between 1989 and the middle of 1996, an estimated number of 170 state enterprises were privatised in Ghana. The most successful and recent privatisations in Ghana are in the areas of telecommunication and 
banking. It is however important to note that privatisation does not always succeed if it is not well coordinated and implemented.

Most privatisation attempts have failed due to poor implementation. It is in this vein that Ngowi (2008) argued that there are possibilities for market failure to occur in the delivery of goods and services by the private sector. He further argued that these goods and services may not be accessible to the poor who cannot afford to pay their market price. Henceforth, in order to reduce the possibilities and intensities of market failure, there is the need to forge strong, effective, efficient, sustainable and vibrant Public Private Partnerships (PPP). Again, Ghana in this light has had its fair share of PPPs in the past. There have been PPPs in the transportation sector, the communication sector, the banking and even at both sea and air ports. The most recent PPP involved urban water delivery which is the focus of this study.

The Ghana Water Company Limited (GWCL) is the government institution charged with the provision of potable water in all urban areas in Ghana. The Ghana Water and Sewerage Corporation (GWSC) was established in 1965 under an Act of Parliament (Act 310) as a legal public utility entity. The corporation operated from 1966 until $1^{\text {st }}$ July, 1999 when it was converted into a Limited Liability Company known as Ghana Water Company Limited under Act 461 as amended under LI. 1648. This move restricted the role of the company to the delivery of only urban water. It is however, important to note that the development of public water supplies in Ghana began in the 1920s with pilot pipe-borne water system managed by the Hydraulic Division of the Public Works Department in Cape Coast and had since undergone several modifications until $1^{\text {st }}$ July 1999 when it was turned into a limited liability company.

In Ghana, water service delivery has been inadequate. Residents do not have constant flow of water with some neighbourhoods getting water once a month. Most houses in Accra though connected to pipelines depend mostly on private operators commonly called "water tankers" for water supply. In effect water is rationed in most urban centers in Ghana. This is similar to what goes on in most developing countries as outlined by Saghir and Shukla (2006) that in many developing countries, water services delivery is inadequate and that people who are even willing to pay for water services are not catered for. Whitfield (2006) blames the unsatisfactory performance of the then GWSC on economic decline during the late 1970s and early 1980s, which led to severe deprivation of investment in the water sector and the loss of skilled manpower from GWSC leading to an unprecedented decline in operational efficiency and leaving one-third of the system inoperable. Meanwhile, the government was subsidising about half of GWSC's operating expenditure because it had placed a ceiling on the tariff level until 1986.

In order to correct these difficulties, several reform initiatives were introduced in the late and early 1970s and 1980s respectively. The interventions were supported by several international and donor organizations including but not limited to the World Bank, Nordic Development Fund, the African Development Bank, Canadian International Development Agency, Department for International Development, Keith Fullerton Whitmans, KFW and Deuche Gesellchaft fur International Zusammenarb - GTZ, Overseas Economic Corporation Fund OECF, and African Development Fund - ADF (Ghana Water Company Limited at a Glance). 
According to the GWCL, though some gains were made from these interventions, their impacts were minimal. In the view of Whitfield (2006) GWSC continued to operate at a loss, with large percentages of unaccounted for water due to leakages and poor revenue collection. Thus, financial recovery was hindered by the exodus of managers and professionals in all sectors in Ghana, lack of adequate financing, and lack of commitment of GWSC staff and external parties engaged in the managerial reforms as well as political interference and corruption.

The litany of problems that engulfed the GWCL became overwhelming and very complex in the 1990s. The World Bank after the launch of the Water Sector Rehabilitation in the early 1990s mooted for private participation in the provision of utilities in Ghana. In 1994, the Bank provided funding for the establishment of a Community Water and Sanitation Division of GWSC which evolved into an independent body namely Community Water and Sanitation Agency established by an Act of Parliament, Act 564 of 1998 (Ghana Water Company Limited at a glance). As mentioned earlier, GWSC was also converted into GWCL as part of the initiative with the mandate for urban water supply only. Other reforms undertaken in GWCL included the establishment of Water Resources Commission and the establishment of the Public Utilities Regulatory Commission (PURC). This phase of the initiative focused on restructuring the urban water sector to involve the private sector in service provision and delivery. Consequently, the Government of Ghana arranged a five-year management contract after extensive review and negotiations with Aqua Vitens Rand Limited from June 2006 to May 2011(Ghana Water Company Limited at a Glance). It must be noted that the contract was signed in October, 2005 but implementation began in 2006.

There is overwhelming literature on privatisation in both developed and developing countries including Ghana. However, a bulk of this literature is skewed toward design, formulation, performance or efficiency (evaluation). Others are on the structural or institutional aspects of privatisation, the politics of privatisation and transparency. The following are some examples of research conducted on the phenomenon; Boakye-Danquah, (2000) "Privatisation, Globalisation and Exports: Some Experiences from Ghana", Whitfield, (2006) "The Politics of Urban Water Reform in Ghana”. Even though, a lot of studies have been done on privatisation, a review of these researches suggests that not much attention has been focused on implementation of privatisation, particularly PPPs. It is against this background that this paper describes and explains the PPP in the delivery of urban water service in Ghana in respect of the implementation process of the management contract between GWCL and AVRL.

\section{Implementation Theory}

Implementation is crucial to the success of public policy. Ineffective implementation could affect the outcome of public policies. According to Grindle (1980), the task of implementation establishes a link that allows the goals of public policies to be achieved as outcomes of governmental activity. She explains that it includes the creation of "policy delivery system" in which specific means are designed and pursued in the expectation of arriving at particular ends. Public policies are usually divided into various projects or programmes. A programme "consists of the actions to achieve the ends of a stated policy. It is apparent that a variety of programmes may be developed in response to the same policy 
goals" (Ayee 2000, p.2). Grindle (1980) also makes a distinction between public policies and action programmes. For policy implementation to be achieved, it is necessary to disaggregate the overall public policy into action programmes that aims at achieving the ends stated in the policy goals.

Implementation is much more complex than it appears. That is why despite the vast body of extant literature on implementation, policy practitioners continue to face the challenge of translating policy goals into concrete results.Policy failures continue to be prominent of implementers' desires' to be informed in appropriate ways by the research community suggests that many implementation challenges remain salient in the world of action $\left(\mathrm{O}^{\prime}\right.$ 'Toole 2000). According to Ripley and Franklin (1986) for implementation to be successful, certain conditions or resources must be available. These resources include personnel, equipment, land, raw materials, and above all money. Secondly, agencies engage in interpretation and planning. They expand the language statutes into concrete directives, regulations, and programme plans and designs. Thirdly, agencies must organise their activities by creating bureaucratic units and routines for attacking their workload. Finally, agencies extend benefits or restrictions to their clientele or target groups. They provide the services or payments or limits on activity or whatever else represents the tangible output of a programme.

Moreover, the model of Sabatier (1980) outlined six conditions for the effective implementation of legal objective. These six conditions were adopted from an earlier work (Sabatier and Mazmanian 1983a) and they include: Clear and consistent objectives, adequate causal theory ( by this point they meant policy interventions should incorporate an implicit theory about how to effectuate social change, they pointed to the adequacy of jurisdiction and policy levers giving implementing officials as a means of ascertaining those causal assumptions), and implementation structures legally structured to enhance compliance by implementing officials and target groups. The other conditions are committed and skilful implementing officials, support of interest groups and sovereigns as well aschanges in socio-economic conditions which do not substantially undermine political support or causal theory.

In short the first three conditions can be dealt with by the initial policy decision (e.g. A statute), whereas the latter three are largely the product of subsequent political and economic pressure during the implementation process.

The main objective of this study is to investigate, describe and explain the factors that influenced the implementation process of the PPP between GWCL and AVRL. The specific objectives include: to explain the extent of clarity of goals and concepts of the contract to implementers, to investigate the adequacy of structures and resources devoted for the implementation of the management contract. to explain the kind of leadership that was provided during the implementation process as well as the effectiveness of the regulatory role of GWCL, to inquire if there was any form of political interference during the implementation process and to probe how PPPs could be improved in the future. When it comes to utility partnerships, regulation of the activities of the private partner by the public partner is very crucial to the success of the partnership. The regulatory role of a public partner in this context can be likened to the supervisory role of an employer over an employee. If the employer fails to put adequate measures to check the attitude of the employee, the employee 
is likely to neglect his or her duty. Like the employer, where a public partner does not perform its supervisory role effectively or diligently, the private partner is likely to underperform.

Rivera (1996) makes the point that the lack of regulatory system; or failure to enforce existing regulations is two of the main causes of unreliable service provided by the public water utilities. They contend that the main goals of regulatory system are to ensure compliance with standards of acceptable service, protect the rate payer from monopolistic behaviour and create a business environment that ensures commercial viability and attract the private sector. The significance of regulation in privatisation cannot be overemphasised. Zhang et al (2005 cited in Prasad 2006) argued that establishing regulatory authority prior to privatisation results in better performance for the operator as well as for consumers. Regulation has become so important that the failure of privatisation has always been blamed on the weaknesses of the regulatory mechanisms. In other words, regulation has become the scape goat allowing the concept of privatisation to prevail (Prasad, 2006).

\section{Conceptual Framework}

The models of Meter and Horn (1975), Sabatier (1980), Ripley and Franklin (1986) and Barrett and Fudge (1975) were used as guide to study the implementation of the management contract between GWCL and AVRL. The model developed from the above models comprised of five factors, which the researcher chose to call explanatory variables. These were believed to have influenced the outcome of implementation. These variables include the degree of clarity of policy goals and objectives, implementation structures, resource, political interference and the nature of leadership during implementation. The degree to which implementers of the management contract understood the policy goals or objectives and standards in the contract document may have impacted on the effectiveness of the implementation process. According to Meter and Horn (1975) policy standards and objectives elaborate on the overall goals of a policy decision and that they go beyond the generalities of a legislative document to provide concrete and more specific standards for assessing programme performance. Consequently, any difficulty in defining the policy objective of the management contract is likely to result in implementation failure. The contract document for example dedicated some pages to definitions of concepts but whether the definitions were exhaustive is another matter. Thus, lack of comprehensive understanding of the standards and objectives on the part of implementers may lead to a situation where implementers would engage in actions that may frustrate the realisation of policy objectives. Therefore, implementers' view of clarity of goals and standards of the management contract is an important determinant in the implementation process.

Also, implementing structures is an important variable in the implementation of the management contract. Implementation structures refer to the administrative arrangement of the implementing agencies of the management contract. Agencies must organise their activities by creating bureaucratic units and routines for attacking their workloads (Ripley and Franklin 1986). Sabatier (1980) also observes the need for legal structures in order to ensure compliance by implementing officials and target groups. The structures outlined for the implementation of the contract had legal statutes; logically, compliance was likely to be high. Thus, availability of structure and their legitimacy could have influenced the 
implementation in any direction; they are therefore important factors to be considered in this study.

Resource is another important factor in determining the effectiveness of implementation of the management contract. Resource in this context includes human, financial and capital resources. For implementation to be successful certain conditions or resources must be available. These include personnel, equipment, land, raw materials and above all money (Ripley and Franklin 1986). The absence or the inadequacy of the above listed resources would adversely affect outcome of implementation. The contract document made mention of $\$ 120$ million, the secondment of staff to the new partner, provision of raw water among others. This could potentially aid implementation if properly utilised. Sabatier (1980) stresses on committed and skilful implementing agencies as key to successful implementation. However, it is important to mention that commitment of implementers partly depends on motivation. As observed by Meter and Horn (1975) inadequate staff and motivation of implementers can lead to policy failure. Consequently, inadequate funding, human resource, motivation as well as lack of commitment that characterise Ghanaian public sector was a huge challenge to the implementation of the management contract and therefore become important determinants of the outcome of implementation.

In sum, the effectiveness of the implementation of the management contract between GWCL and AVRL may be explained by the three main variables discussed above. These factors may be referred to as variables or explanatory variables.

\section{Methodology}

In order to achieve the objectives of the study, the case study strategy within the qualitative paradigm was used. This is because it involves an in depth or intensive descriptions and analysis of a single unit or bounded system. The choice of the qualitative approach was to allow for a deeper understanding of the processes of how implementers of the partnership between GWCL and AVRL conducted and interpreted events during the implementation with respect to the explanatory variables. Also, the qualitative approach gave respondents the platform to express themselves on issues concerning the implementation of the partnership between GWCL and AVRL. It also afforded the researcher an opportunity to be involved in a sustained and intensive interaction with the participants. One advantage of qualitative study is makes use of multiple sources of data which enriches the study. The adoption of this approach was necessary because it ensured the detailed description of the issues by the implementers.

The sampling method used for selecting institutions and respondents for the study was purposeful sampling. The institutions were selected because they were either directly or indirectly involved in the implementation process of the management contract. The institutions used for the study were GWCL, AVRL, PURC, the Ministry of Water Resources Works and Housing. The civil society organisations included ISODEC, CONIWAS and NCAP. The Public Utility Workers Union of TUC was also included in the study. A total of twenty (20) informants were targeted. However, nineteen (19) were interviewed for the study. The research instrument used for this study was the in-depth interview method. The interview method was chosen because the research is a case study and therefore required an instrument 
that affords the respondent the opportunity to provide in depth and unrestricted information about the subject. The interviews were conducted over a period of four months in two parts. The first part began on November 15, 2011 to December 21, 2012 and the second batch of interviews was carried out in mid-February.

The interviews that were conducted in the field were transcribed and those that were handwritten were typed. These transcripts were sorted and studied carefully in order to get a deeper understanding of the data collected. The researcher then went ahead to classify the data into various themes for easy analysis. The classification was done according to the themes on the interview guide. The themes were analysed taking into consideration the research objectives and questions respectively. The analysis involved the rendering of a detailed description of the data in a form of a narrative. Through the analysis, the researcher identified the findings inherent in the data, thereby bringing out her personal understanding of the data as well as lessons and conclusions drawn from the study. Direct quotes were used where necessary throughout the report in order to bring out implementers account of the implementation. Issues of ethical concerns constantly arise in social science research because it mostly involves human participants. In order to avoid or at least minimise such issues, participation in this research was purely based on the participants own volition. Thus, their informed consent was obtained.

\section{Results and Discussion}

\subsection{Grey Areas - Issues on Clarity of Goals and Interpretational Difficulties}

There were several concerns under the issue of clarity of goals and concepts. While implementers agreed the goals of the management contract were clear, they nevertheless agreed that actual implementation was challenging. The difficulty in implementation was attributed to fact that there were a number of grey areas; that is interpretations and definitions of certain concepts were ambiguous and as such resulted in delays in implementation. Examples of such concept are CRT, "in consultation" and even the value of NRW. This particular finding appears to be contradictory because most respondents claimed the goals and concepts in the management contract were clear but at the same time complained there were grey areas. So where is the clarity when the grantor and the operator could not come to terms on basic definitions of concepts?

... The goals were clear theoretically but when it came to implementation that is where we have interpretational challenges. The document was clear as to the quantitative and qualitative indicators which were being used in monitoring. As I said during the course of implementation, we run into some interpretational and definitional problems

The inability of both parties to agree on concepts led to unnecessary delays which may explain why the implementation was not very successful according to respondent and the Performance Report (2010). This finding also confirms the assertion that the extent to which implementers understand the policy standards and objectives directly influence the effectiveness of implementation (Meter and Horn 1975). The delays in the implementation may be seen as an implementation challenge due to the ambiguity of certain concepts in the 
management contract.

Another finding as regards clarity of goals had to do with the issue of weak foundation. Programmes and projects such as the procurement and installation of bulk or zonal meters had not been put in place before the commencement of the management contract. Also there were no agreements on certain baselines such as what constitute Customer Response Time before the commencement of the implementation. This finding is corresponding to the argument that implementation depends on programme outcomes and that it is difficult to separate the fate of policies from that of their constituent programme (Grindle 1980).

\subsection{Structural Arrangement: A Referee or a Player}

The institutions established for the implementation were adequate for the implementation. However, the findings revealed what appeared to be conflict of interest on the part of the grantor due to its additional role as a supervisor. The arguments of implementers were that GWCL as an asset holder had a role to play as contained in section four of the contract document. For instance, section 4.3 of the management contract makes reference to the payment of the operator in accordance with the terms of this management contract.

Also, section 4.4.2 of the management contract states that the grantor shall use its best efforts to secure adequate finance pursuant to the project as defined herein to fund any capital investment programme and shall keep the operator informed of the progress of such applications and negotiations. Another role of the grantor was the supervision of the activities of the operator, which according to most respondents was poorly executed. This implies that the inability of GWCL to perform its role, affected the performance of AVRL directly. The problem was therefore about who the GWCL was answerable to in the event it failed to perform its role. One may argue on the basis of the above analysis, that implementation could have been better had there been an independent supervisor to monitor GWCL.

The asset holder overseeing the contract may be there could have been an independent body to look at the work of both parties

This finding is in line with Bayliss (2001) that weak regulation, and absence of independent regulator can affect management contracts. The issue of an independent supervisor was even much glaring as most informants, especially from the AVRL had the impression that GWCL wanted the downfall of AVRL; as a result they perceived staffs of GWCL not committed to the management contract. All these internal wrangling could have been avoided had there been an independent supervisor.

Similarly, the study found that the past relationship between the staffs of GWCL and AVRL affected implementation process especially in the area of supervision.

Also, there was a problem because we were monitoring our own people. It so happened that we were supposed to be monitoring AVRL but the people we were to monitor were our colleagues, some of them were our seniors. In my view, it was a weak link in the whole structural arrangement process and I would have preferred a very independent unit, 
well-staffed with professionals possibly from outside the organisation to undertake monitoring activities

The Ghanaian culture of reverence for the elderly also made things very difficult for some of the supervisors to thoroughly monitor the activities of some seconded staff. This was partly because the seconded staff had previously served as superiors to their newly appointed supervisors. This often led to situation where the seconded staff behaved as if they were still superior to the newly appointed supervisors. This point consistent with Ayee (2000) that policy failure must be considered within the overall political and societal context.

The study further revealed that there were a number of bureaucratic bottlenecks, which led to delays in the implementation process. According to respondents they have to go through several procedures before funds could be released from the World Bank. Informants believed that bottlenecks were however blessings in disguise as they served as checks on the way funds were disbursed.

\subsection{Resources: Albatross or Seconded Staff}

Both human and financial resources are crucial to the effective implementation of any public policy. Grindle (1980); Meter and Horn (1975) and Ripley and Franklin (1986) have underscored the importance of resource to effective policy implementation. Findings from the field showed that the financial resources provided for the implementation of the management contract was adequate. Human resource per the data collected was also reported as adequate. However, a review of the fourth year technical audit report in 2010 showed that human resource became a challenge in certain areas. Indeed, the report blamed certain failures on the part of the operator on inadequate human resource.

On the skills of the staff (local and expatriate), it was gathered that the local staff were very skilful and experienced. On the contrary, the expatriate staffs otherwise known as the operator staffs were perceived not as skilful and experienced as their Ghanaian counterparts. This may be explained by the allegation by some respondents that the operator presented staff that possessed skill and experience different and far below those mentioned in the bidding document.

Yes we have fairly qualified staff, in terms of human resource I would say is not bad. However the expatriate staff compared to the local staff does not match, the names that were provided in the bidding documents were not the ones brought to Ghana. Most of them were not just up to scratch

The study further revealed that the operator had a difficulty in dealing appropriately with seconded staff. This implies that the operator could not discipline or reward seconded staff without consulting the grantor.

Was AVRL supposed to work with seconded staff to the extent that it became an albatross because of the staff seconded to them? The operator's hands were tied because there were 
certain clauses in the contract that made it difficult for the operator to discipline those staff because they did not recruit them. They did not have the authority to discipline them and that affected performance because precious time was spent on litigating labour issues. If certain things were done right and if freedom was given to the operator, I think we should have achieved better results

This development became a major impediment as decisions of the operator were often delayed as a result of that caveat. The caveat may also explain why there were shortages in human resource in certain parts of the country and as such the poor performance of AVRL in those regions. This goes to support the argument that inadequate staff and motivation for implementers can result in implementation failure (Meter and Horn 1975). There were also serious challenges in respect of the capital and material resources. As reported by respondents and confirmed by the technical audit report of 2010, bulk meters were not fully installed and even those installed were not commissioned before commencement of implementation (Performance Report 2010). In the same vein, the grantor at the end of the fourth year had not agreed to the operator's definition of customer response time: that is how long it took the operator to respond to complaints made or problems reported by customers. The difficulties with securing the necessary resources may be cited as one of the reasons why the management contract was not effectively implemented and this is in line with Ripley and Franklin (1986) that successful implementation is dependent on certain conditions or resources including personnel, equipment, land, raw materials and above all money.

\section{Conclusion}

Considering the impact of public policy on policy beneficiaries and the challenges that implementers encounter in the course of implementation, it is imperative that measures are put in place to mitigate the negative impact of unsuccessful implementation. In the light of this the paper makes the following recommendations: 1. Government should consider developing options to promote adequate and sustainable delivery of water in urban areas. This can be done in concert with other stakeholders such as international partners, civil society groups in the area of water as well as policy implementers. 2 . The solution to the problems of GWCL is not necessarily changing the management. As revealed by the findings of the study, the problems are deeper than inefficient or ineffective management. The bane of the company is the lack of adequate capital injection. The GWCL suffered from the lack of capital injection during the period of Structural Adjustment Programmes. Consequently, most of the infrastructure, including pipelines is old and damaged. Most of the facilities have been used for decades and have not been expanded or replaced, meanwhile the population of the country has grown phenomenally. It is therefore the opinion of the researcher that more capital should be injected into the sector to make it more viable. 3. Also, policy makers may consider a review of the content and process of wording of the future policies by allowing for active participation of the workers in future. Their experiences and knowledge may provide policy makers with important input to enable them make informed decisions regarding the future and direction of GWCL and other related public service organisations. 4. In respect of implementing structures, there is the need for designated institutions, with defined roles for implementing public policies in order that the overlapping roles and conflicting interests of 
implementing institutions may be avoided. 5. There is also the need for strong foundation to be built prior to implementation. This could include the clearing of outstanding issues, the provision of the necessary resources for implementation, making the acquisition of resources reasonably flexible as well as providing a congenial environment for implementation.

Given the above discussions, one can say that the challenges of policy implementation are multifaceted. This study revealed some of the challenges that confronted policy makers in the implementation of PPP with specific reference to the management contract between GWCL and AVRL. These challenges highlighted the implementation realities in the implementation of the partnership in urban water service delivery in Ghana. Even though, the partnership was not so successful, it could have been better if the implementation challenges were minimised.

A management contract is supposed to be a typical alternative to public provision of utilities by trying to be more competitive in the capitalistic sense. Therefore, one would not be wrong to say that such partnership could be more successful in areas where implementation mechanisms are tailored in a more capitalistic form. In other words, where institutions are allowed to operate free from government interventions; who unduly swing prices in favour of poor neighbourhoods all in the name of social interventions and for their parochial political interests, policy implementation is likely not be effective.

The implementation of the management contract in Ghana may have faced the difficulties it encountered because the special circumstances in Ghana do not allow the market to operate fully, especially in the sector of public utilities such as water.

\section{Acknowledgement}

Our sincere appreciation goes to Ghana Water Company Limited (GWCL), Aqua Vitens Rand Limited (AVRL), and Public Utility Regulation Commission (PURC). I also express my appreciation to the Ministry of Water Resources Works and Housing and all the civil society organisations that supported in the study including National Coalition against the Privatisation of Water (NCAP), Coalition of NGO's in Water and Sanitation (CONIWAS) and Integrated Social Development Center (ISODEC) and the Public Utility Workers Union of the Trades Union Congress. Finally, we thank all individuals who helped in making this paper a success.

\section{References}

Andres, A., Guasch, J.L., Haven, T. and Foster, V. (2008).The Impact of Private Sector Participation in Infrastructure - Lights, Shadows and the Road Ahead. Washington DC: The World Bank.

Ayee, J.R.A. (2000). Saints, Wizards, Demons, and Systems: Explaining the Success or Failure of Public Policies and Programmes. Accra, Ghana Universities Press.

Ayee, J.R.A. (ed), (2007). Ghana at 50: Government, Politics and Development.Department of Political Science, University of Ghana, Legon, Ghana and Friedrich- Ebert-Stinftung, Ghana.

Bayliss, K. (2001). Water Privatisation in Africa: Lessons from Three Case Studies. Public Service International Research Unit. 
Bayliss, K. (2003). Utility Privatisation in Sub-Saharan Africa: A Case Study of Water.The Journal of Modern Africa Studies, Vol. 41, No. 4, PP.507-531.Cambridge University Press.Accessed on February 21, 2011 from http://www.jstor.org/stable/3876352

Boakye-Danquah, Y. (2000). Privatisation, Globalisation and Exports: Some Experiences from Ghana. The Journal of Management Studies, Vol. 15, No. 1, School of Administration, University of Ghana, Legon.

Creswell, J.W. (2007). Qualitative Inquiry and Research Design: Choosing Among Five Approaches. Thousand Oaks, California, Sage Publications Inc.

Domfeh, K.A. (2001). Private Sector Participation in Solid Waste Management in Accra.Unpublished Ph.D. Thesis, University of Ghana.

Grindle, M.S. (1980). Politics and Policy Implementation in the third World Countries.Princeton University Press.

Grindle, M.S. and Thomas, J.W. (1991).Public Choices and Policy Change: The Political Reform in Developing Countries.Baltimore and London, John Hopkins University Press.

Merriam, S. (2000).Qualitative Research and Case Study Applications in Education. Francisco, USA, Jossey-Bass Publishers.

Ngowi, H.P. (2008). Privatisation and Agentification of Public Services Delivery in Africa: Extent and Managerial Implications in Tanzania. Council Development of Social Science Research in Africa. Africa Development, Vol.XXXIII, No. 4, pp.97-116.

Okecho, W. (1992). Towards the Reform of State - Owned Enterprises in Uganda in Ochieng (ed) Selected Public Lectures of the Ugandan Economics Association- Privatisation in Uganda. Kampala, Uganda. Friedrich Ebert Foundation.

O'Toole, L.J. (2000). Research on Policy Implementation: Assessment and Prospects. Journal of Administration Research and Theory, Vol.10, No.8, PP.263-288.

Prasad, N. (2006). Privatisation Results: Private Sector Participation in Water Services after 15 Years.Development Policy Review. Overseas Development Institute No. 24 (6): 669-692,

Rivera, D. (1996). Private Sector Participation in Water Supply and Wastewater Sector-Lessons from Six Developing Countries. Washington, DC. The World Bank.

Ripley, R.B. and Franklin, G.A. (1986).Policy Implementation and Bureaucracy.Chicago, the Dorsey Press.

Sabatier, P.A. (1980). Top-down and Bottom-up Approaches to Implementation Research. In Sabatier, P.A. (ed), Why Policies Succeed or Fail. Beverly Hills, California, Sage Publications.

Saghir, J. and Shukla, J. (2006).Approaches to Private Participation in Water Services - A Toolkit. Washington, DC. The World Bank.

Tati, G. (2005). Public Private Partnership (PPP) and Water - Supply Provision in Urban Africa: The Experience of Congo-Brazzaville. Development in Practice, Vol.15. No. 314, PP. 316-324. Taylor and Francis Ltd. on behalf of Oxfam GB.Accessed February 22, 2011 from http://www.jstor.org/stable/4029964.

Van Meter, D and Van Horn, C. (1975). The Policy Implementation Process: A Conceptual 


\section{Macrothink \\ Journal of Public Administration and Governance \\ ISSN 2161-7104 \\ 2013, Vol. 3, No. 1}

Framework.Administration and Society, Vol.6, PP.447.

Whitfield, L. (2006). The Politics of Urban Water Reform in Ghana.Review of African Political Economy, Vol.33.No.109, Mainstreaming the African Environment in Development, PP.425-448.Taylor and Francis Ltd. Accessed February 22, 2011 from http://www.jstor.org/stable/4007051.

Yin, R.K. (2003).Case Study Research: Design and Methods.Thousand Oaks, California, Sage Publications.

Young, R.A. (1991). Privatisation in Africa.Review of African Political Economy, No. 51, pp. 50-62. Taylor and Francis, Ltd. Accessed on February 15, 2011 from http://www.jstor.org/stable/4006050.

Zhang, Y., Parker, D. and Kirkpatrick, C. (2005). Competition, Regulation and Privatization of Electricity Generation in Developing Countries: Does the Sequencing of the Reforms Matter? Quarterly Review of Economics and Finance, Vol.45, No.2-3, PP. 358-79.

\section{Glossary}

Grantor: Ghana Water Company Limited, a limited liability company wholly owned by the Republic of Ghana

Operator: Aqua VitRa Limited, a limited liability company registered under the laws of the Republic of Ghana

Seconded Staff: staff of Grantor transferred to the Operator

\section{Appendix 1}

\section{Interview Guide}

The following is an interview guide in partial fulfilment of the award of Master of Philosophy (MPhil) in Public Administration. The topic under study is "Implementing Public Private Partnerships in Ghana: The case of Urban Water Service Delivery". This exercise is strictly for academic purpose. The identity of respondents and responses shall not be revealed or used in any way that will be injurious to the personality of respondents. The researcher will therefore be very grateful if you would give the necessary assistance to facilitate the data collection.

\section{A. Background of Respondent}

1. Name of respondent

2. Institution of Respondent

3. Position of Respondent in the institution

4. Number of years respondent has been with the institution

5. Gender

B. Clarity of Goals

1. What was the main goal of the management contract?

2. What were the specific objectives of the management contract? 


\section{Macrothink \\ Journal of Public Administration and Governance \\ ISSN 2161-7104 \\ 2013, Vol. 3, No. 1}

3. In your opinion, were the goals or objectives clear and easy to understand?

4. Were concepts or terminologies in the contract well defined and interpreted?

\section{Structural Arrangements}

1. Kindly outline the processes put in place for the accomplishment of the goals and objectives of the management contract?

2. Were these processes adequate for the accomplishment of the task?

3. Please explain your answer.

D. Resources

1. Would you say there was adequate financial resource for the accomplishment of the task?

2. Please explain your answer.

3. Would you say there was adequate human resource for the performance of technical services?

4. Please explain your answer.

5. Did the human resource possess the appropriate skills for the achievement of objectives or goals of the management contract?

6. Were there adequate financial resources for the achievement of the goals in the contract?

E. Challenges

1. Can you list any three challenges you faced in the implementation process?

2. How did each of them affect the outcome of the management contract?

3. What is your general opinion for undertaking such a policy?

Thank you, 


\section{Macrothink}

\section{Appendix 2}

\section{Model of Population}

\begin{tabular}{|l|r|l|}
\hline $\begin{array}{l}\text { Name } \\
\text { Institution }\end{array}$ & Number of Respondents & Positions of Respondents \\
\hline GWCL & 7 & 1 lawyer \\
\hline & & 2 officers from monitoring division \\
\hline & & 3 managers \\
\hline AVRL & 4 & ex-finance manager from PMU \\
\hline & & Public Relations Officers \\
\hline & & General Manager Strategic Planning \\
\hline PURC & 3 & Business Planning and Reports Manager. \\
\hline & & Assistant Technical Manager \\
\hline & & Manager of the Water Directorate \\
\hline Ministry of Water & 1 & Water and Sanitation Engineer \\
\hline ISODEC & 1 & Essential Service Campaign \\
\hline NCAP & 1 & Member \\
\hline CONIWAS & 1 & Executive Secretary CONIWAS \\
\hline TUC & 1 & Secretary of PUWU \\
\hline
\end{tabular}

